\title{
Nuclear Garbage Proposal for the Marshall Islands
}

In the Spring issue of this Journal we discussed* an outrageous proposal to use one of the Marshall Islands Atolls as a gigantic dump for solid wastes from the western United States. suggesting that if this were permitted it would only be the beginning - that the beautiful Marshall Archipelago could ultimately become a garbage dump for the world.

Now, before that proposal is safely dead, an incredible next step is the subject of serious discussion between US officials and the Head of Government of the Republic of the Marshall Islands. This new proposal is to use Erikub Atoll, one of the smaller but centrally-situated Marshalls $t$, as a depository for high-level nuclear waste from the US and possibly also Japan. Erikub is one of the atolls with some intact native forest remaining-enough to be suggested by a recent MacArthur Foundation-sponsored survey as a site for the preservation of natural biological diversity in the Marshalls. Erikub is currently uninhabited, but is used for copra production by the people of nearby Wotje Atoll. $t$ It is also considered a site of traditional cultural and religious significance to those people.

The irony of this situation is that these discussions are taking place at the same time as the US Government is being asked by the Marshallese people to spend scores, if not hundreds, of millions of dollars to clean up nuclear waste produced by the atomic-weapons testing 40 years ago on Bikini Atoll, not far away in the same Marshall Archipelago. $\dagger$

This time the enormous economic power of the US (and possibly also Japan) will be just as irresistible to the Marshallese as US military might, and the claim that the testing was for the good of humanity, were in the 1940s.

\footnotetext{
* 'Garbage Dump in the Marshall Islands?'. by Dr F. Raymond Fosberg. Envirommental Conservation, Vol. 16. No. 1. pp. 78-9 with 3 maps. Spring 1989.-Ed.

+ See Fig. 2 on p. 78 of our Spring 1989 issue. - Ed.
}

After 30 years and more of groping and desperately trying to find a safe and acceptable solution to the nuclear waste problem in the US, the authorities contemplate arranging for the problem to go away by making pollution in another part of the world so economically attractive to a poorer people that they will accept the risks which are refused by the people of the US.

Dumping of this material in the World Ocean is considered so undesirable that even the dumping of low-level waste, such as the topsoil from Bikini Atoll, is prohibited by international agreement. What is apparently not realized-or perhaps is being ignored-is the fact that the ground-water bodies in atoll islets are effectively part of the sea-water system, with a constant flux from the freshwater lens in an islet into the sea and lagoon. Nuclear pollution, as soon as the containers disintegrate, will leak and be washed into this ground-water by rainfall, and be diffused out into the sea-water-to pollute the fish that the Marshallese, and even the Japanese and Russians, catch and eat.

Pollution of the ocean is now being perceived as a reality, so that strong public pressure is being brought against it. When general awareness develops that pollution of any kind which is or becomes soluble, occurs on a coral island is effectively marine pollution, it will be stopped. However, as with nuclear and toxic-waste pollution everywhere else, by the time realization and public pressure develops, cleaning up has become prohibitively expensive or practically impossible. Public awareness appears always to be too slow-'too little and too late'. We seem determined to make our planet uninhabitable for our descendants.

F. RAYMOND FOSBERG, Botanist Emeritus
National Museum of Natural History
Smithsonian Institution
Washington
DC 20560, USA.

\section{UNEP's Oceans and Coastal Areas Programme Activity Centre}

The environmental problems associated with the potential impact of expected climate changes may well prove to be among the major environmental problems facing the marine environment and adjacent coastal areas in the near future. Therefore, the Oceans and Coastal Areas Programme Activity Centre (OCA/PAC) of the United Nations Environment Programme (UNEP) launched, coordinated, and financially supported, a number of activities designed to assess the potential impact of climate changes and to assist the involved governments in identification and implementation of suitable response measures which may mitigate the negative consequences of the impact.

In 1987, Task Teams on Implications of Climate Change were established for six regions covered by the UNEP Regional Seas Programme (Mediterranean, Wider Caribbean, South Pacific, East Asian Seas, South Asian Seas, and South-East Pacific) with the initial objective of preparing regional overviews and site-specific case-studies on the possible impact of predicted climate changes on the coastal and marine ecological systems, as well as on the socioeconomic structures and activities of their respective regions. The establishment of two additional Task Teams (for the West and Central African region and for the Eastern African region, respectively) is now in process.

The regional studies have been planned to be presented to intergovernmental meetings convened in the framework of the relevant Regional Seas Action Plans, in order to draw the countries' attention to the problems associated with expected climate change and to prompt their involvement in the development of policy options and response measures that would be suitable for their region. The site-specific case-studies were planned to be presented to national seminars.

The preliminary results of the regional studies (overviews) of the Task Teams have already been considered by meetings convened under the Mediterranean, Caribbean, South Pacific, South-East Pacific, and East Asian, Seas Action Plans. One site-specific case study (Delta of Nile) was presented at a national seminar already in December 1988. Two additional seminars have been planned for 1989 (Delta of Po and Thermaikos Gulf).

A special intergovernmental meeting was convened in mid-1989 in the Marshall Islands, for the 19 island States of the South Pacific to consider their policy options, suitable response mechanisms, and additional site-specific casestudies that are yet to be developed. Also, a detailed casestudy on the Maldives has been prepared with the assistance of the South Pacific and the Mediterranean Task Teams, and will probably lead to a large-scale country-wide project.

When once the initial objective of the Task Teams (impact studies) has been achieved, they will concentrate on 
providing assistance to national authorities in defining specific policy-options and suitable response measures.

The development of climate scenarios for the Mediterranean region has been initiated. They are planned to be completed in 1990, and to be used in connection with the revision of the Mediterranean regional study.

On a global scale, a review of the interaction of the oceans with 'greenhouse' gases and atmospheric aerosols has been published, and a bibliography on the effects of climate change and related topics has been prepared by the Mediterranean Task Team.

StJePAN KeCKes, Director
Oceans and Coastal Areas Programme
Activity Centre
United Nations Environment Programme
P.O. Box 30552
Nairobi, Kenya.

\section{Global Education Associates}

This body, commonly referred to by its acronym of GEA, was founded in 1973 as a response to the realization that we live in a new era - a historic transition in which the futures of all individuals, groups, and nations, are irreversibly interconnected.

GEA is a network of individual and institutional associates in more than 80 countries, seeking to empower people to become active participants in shaping a more just, peaceful, and sustainable, world future. The Associates are united in a common world-view that recognizes the oneness and sacredness of the whole earth community, including the Planet Earth itself.

The historical roots of Global Education Associates are in 20 years of development work by its founders, the undersigned, in local self-help community development programmes in Latin America and East Africa. This experience bore witness that, in today's interdependent world, local and global concerns are profoundly intertwined. GEA was founded with awareness that non-governmental organizations-secular and religious-around the world must join hands as bold, creative actors in this pivotal transition period in human history.

GEA's associates work together to catalyse a transnational multi-issue movement for policies and structures capable of responding to the crises and opportunities of today's interdependent world. Special emphasis is placed on reconceptualizing security and sovereignty within the context of ecological and economic interdependence. Towards this end they conduct research; organize public and leadership seminars; produce publications and audiovisuals; sponsor and conduct public education programmes; offer consulting services; and facilitate networking at local, national, and international, levels. Their programs and publications are designed to advance cooperative win-win solutions to today's critical global-scale problems.

The appended 'Highlights of 16 Years: An Overview Report' lists some of GEA's accomplishments and describes some of its projects and programmes.

$$
\begin{aligned}
& \text { Gerald F. Mische, President } \\
& \quad \& \\
& \text { PATRICIA MiSCHE } \\
& \text { Global Education Associates } \\
& \text { Suite } 456 \\
& 475 \text { Riverside Drive } \\
& \text { New York } \\
& \text { NY 10115, USA. }
\end{aligned}
$$

\section{HighlightS OF I6 YeARS: \\ AN OVERVIEW REPORT \\ Global Education Associates}

GEA is an international network of men and women in more than 80 countries who conduct research, policydevelopment seminars, and educational programmes, aimed at advancing world peace and security, cooperative economic development, human rights, and ecological sustainability.

1) GEA is a growing global network of associates in over 80 countries.

2) More than 2,500 workshops, institutes, and symposia, have been conducted by GEA staff and associates around the world.

3) The International Center for World Order Alternatives has been established in New York City. The first group of international scholars is scheduled for the 1989-90 programme year.

4) The Asian Institute for a New World Order, opened in Manila, Philippines, in 1987, links individuals, institutions, and organizations, in Asia in research and educational programmes focusing on Asian perspectives for world order alternatives. GEA associates are working to develop parallel regional institutes in Africa, Europe, and Latin and North America.

5) Partners for World Order Alternatives : Building on its experience of multi-issue and movement-building and global networking, GEA initiated a collaborative partnership that links a growing number of organizations and institutions around the world in a process of reconceptualizing security and sovereignty in a context of global interdependence.

6) Project Global $\mathbf{2 0 0 0}$ is the central programme expression of the above partnership. It is designed to produce global-frame documents in 50 countries that will examine the interrelated issue areas of global security. environment, debt and development, health, landagriculture, human rights, and global spirituality, in the context of global interdependence. Its research and outreach programmes focus on policy and systems development that should be achievable during the 1990s.

7) More than $\mathbf{5 0}$ religious networks, most of which are transnational, have become formal partners with GEA, which has conducted workshops for their leadership and general membership, and facilitated their involvement in concrete projects around the world.

8) A 17-parts' television series for CBS, based on the Misches' book, Toward a Human World Order, was developed by GEA staff and associates.

9) Accredited graduate-level institutes on global issues and interdependence have been conducted by GEA staff and associates at more than 25 universities around the world.

10) The Earth Covenant: A Citizens' Treaty for Common Ecological Security: A Soviet-American initiative to establish and institutionalize the right to a healthful environment and to develop a world-wide consensus on principles, policies, and systems, for ecological security.

11) Publications Breakthrough - a quarterly publication The Whole Earth Papers - a series of monographs International Perspectives in Public Health-a scientific journal. 